\title{
Human Islet Cell Adenoma: Metabolic Analysis of the Patient and of Tumor Cells in Monolayer Culture*
}

\author{
K. Adcock, M. Austin, W. C. Duckworth, S. S. Solomon and L. R. Murrell \\ Dept. of Anatomy, Univ. of Tennessee Center for the Health Sciences and Veterans Administration Hospital, Memphis, Tennessee, \\ U.S.A.
}

Reveived: April 1, 1975, and in revised form: August 4, 1975

\begin{abstract}
Summary. Cell cultures were established from a benign pancreatic islet adenoma. Over $200 \mu \mathrm{U} /$ culture/day immunoreactive insulin were found in culture media. Cultures with medium 199 released insulin for about 2 months; those with medium F12K were maintained for over 7 months, and have been successfully subcultured. Increasing culture medium glucose to $326 \mathrm{mg}$ per $100 \mathrm{ml}$, alone or with leucine $(10 \mathrm{mM})$ or theophylline $(2 \mathrm{mM})$, failed to increase insulin release above baseline. Studies in the patient prior to surgery using oral glucose, leucine, beef meal, intravenous tolbutamide, and glucagon failed to increase plasma insulin and thus were consistent
\end{abstract}

with cell culture responses. Extracts of tumor tissue contained $23 \%$ proinsulin-like material; high insulin containing samples of culture medium had $5 \%$ proinsulin and less than $40 \mathrm{pg}$ glucagon $/ \mathrm{ml}$. Aldehyde fuchsin positive granulation was sparse in both cultured cells and the original tumor. These studies demonstrate long term viability, in monolayer culture, of cells derived from this islet cell adenoma, with retention of secretory characteristics consistent with data obtained prior to removal of the adenoma from the patient.

Key words: Insulin, islet adenoma, monolayer culture.
Adult pancreatic islet cell adenoma has been difficult or impossible to maintain in long term cell culture, and to date successful long term subculture has not been reported. The first attempt to culture pancreatic islet neoplastic tissue was reported in 1935 [1], though hormone synthesis was not demonstrated at that time. Three recent papers $[2,3,4]$ dealing with primary cultures of human islet cell tumors have demonstrated insulin synthesis and/or release in vitro. Subcultures have either not been reported $[2,3]$ or have been followed for only a few days [4].

In general, the techniques of differentiated cell culture have not been fully exploited for this rare tumor, though the applicability of monolayer culture techniques for studies of pancreatic B-cells has been well documented $[5,6,7,8,9]$. We have recently been successful in culturing cells from a benign islet cell adenoma. Viable cells capable of synthesizing and releasing insulin have not only been maintained in primary culture for over seven months, but have been successfully subcultured. Furthermore, few reports of cell cultured insulinomas have included comparative metabolic studies of the patient and of tumor cells in vitro. Herein we report the results of in vivo challenge of the patient in comparison with in vitro challenge of cultured tumor cells by known insulin secretogogues.

\footnotetext{
* Some of the data presented here have appeared in abstract form in Diabetes, 23: 363, 1974
}

\section{Methods}

\section{Clinical Background}

The patient, a 26 year old non-obese American Negro male, had a 4 year history of generalized tonicclonic seizures, not controlled by Dilantin (sodium 5, 5-diphenyl-2,4 imidazolidinedione) and phenobarbital. Medications were discontinued prior to the studies reported here. His primary clinical manifestations typically occurred in the absence of food, andresponded to oral or intravenous glucose. Although stimulated serum insulin levels were never found to be above $100 \mu \mathrm{U} / \mathrm{ml}$, an inappropriately high insulin: glucose ratio was consistently demonstrated. A 1.0 $\mathrm{cm}^{3}$ tumor was demonstrated angiographically and surgically excised from the head of the pancreas. The patient has been asymptomatic for over 18 months since surgery.

\section{Culture Methods}

Immediately following gross pathological evaluation of the excised tumor, approximately $100 \mathrm{mg}$ (wet weight) of the tumor was placed in ice cold Hanks' saline [10], transported to the laboratory, cut into fragments of 1 to $3 \mathrm{~mm}^{3}$ and placed in $60 \mathrm{~mm}$ Petri dishes or in $30 \mathrm{ml}$ culture flasks (Falcon). Glass coverslips to anchor explants in the Petri dishes and re- 
duction of medium volume in flasks allowed maximum contact between tissue fragments and culture vessel surface. Medium was changed approximately every 4 days during the first two weeks of culture after which densities of cellular outgrowth determined longer intervals between medium changes.

Tissue fragments cut from the outgrowing cells after 10 or more days in culture were subsequently cultured in $60 \mathrm{~mm}$ Petri dishes. Coverslips originally used to anchor tissue fragments in primary cultures were placed in separate Petri dishes: cells attached to these coverslips remained viable following such transfer. Subcultures were prepared by enzymatic dispersal of primary cultures using $0.01 \mathrm{~g}$ collagenase (Worthington Biochemicals, CLS grade), $0.01 \mathrm{~g}$ trypsin (Difco, $1: 250), 1 \mathrm{ml}$ chicken serum [11], and $0.4 \mathrm{~g}$ methyl cellulose U.S.P. (15 centipoise) diluted to $100 \mathrm{ml}$ with Moscona saline [12]. This solution, designated $\mathrm{CTCm}^{1}$, was also used to disperse cells from confluent subcultures to prepare further generations of subcultures.

All cultures were maintained at $37^{\circ} \mathrm{C}$ in a waterjacketed incubator supplied with continuously flowing carbon dioxide in air. Carbon dioxide levels varied from $2 \%$ to $5 \%$, dependent on the culture medium buffer system, to maintain $\mathrm{pH}$ at $7.3 \pm 0.2$.

\section{Culture Media}

Cultures were established and maintained either in medium F12K [13] made in our laboratory, or in medium 199 [14] obtained commercially. Both media were supplemented with either $5 \%$ or $10 \%$ fetal calf serum, and with $0.01 \mathrm{M}$ HEPES buffer. Pools of fetal calf sera were previously titrated using a cloned diploid rat cell line [11] to determine optimum concentration. Media used for primary cultures also included penicillin $(50 \mathrm{U} / \mathrm{ml})$ and streptomycin $(50 \mu \mathrm{g} / \mathrm{ml})$. Medium F12K contains $126 \mathrm{mg}$ glucose per $100 \mathrm{ml}$; medium 199 contains $100 \mathrm{mg}$ glucose per $100 \mathrm{ml}$. Total medium glucose was increased for some cultures by adding glucose to a final concentration of $326 \mathrm{mg}$ per $100 \mathrm{ml}$ for $\mathrm{F} 12 \mathrm{~K}$, or to $300 \mathrm{mg}$ per $100 \mathrm{ml}$ for medium 199. All culture media were pressure filter sterilized through pre-washed membrane filters (Millipore, 0.22 micron pore size).

\footnotetext{
1 Abbreviations used in this paper: CTCm - collagenase trypsin - chicken serum - methyl cellulose, in concentrations given in text; HEPES - N-2-hydroxyethylpiperazine-N-2-ethanesulfonic acid; IRI - immunoreactive insulin; RIA - radioimmunoassay; Cyclic AMP - cyclic 3' 5'-adenosine monophosphate.
}

\section{In Vivo and In Vitro Stimulation}

Oral and intravenous glucose tolerance, oral leucine, Tolbutamide (1-butyl-3-p-tolylsulfonlyurea) tolerance, and glucagon infusion tests were performed by standard methods (see "Results"). In all tolerance tests, insulin and glucose were measured in blood samples drawn at appropriate intervals for 180 or more minutes after administration of the test compound. For in vitro stimulation, growth media were removed from cultures, and replaced by equal volumes of identical media supplemented with the appropriate concentrations of the test compound(s) leucine, theophylline, and/or glucose.

\section{Analytical Methods}

Glucose was measured by the procedure of Brown [15] using a Technicon Autoanalyser (Technicon Instruments Corp., Tarrytown, N. Y.). IRI was measured by modifications $[16,17]$ of competitive RIA [18], using crystalline porcine insulin standards (Eli Lilly Co., Indianapolis, Indiana). Crystalline porcine glucagon standards (also from Eli Lilly Co.) were used for RIA of glucagon by the method of Unger et al. [19]. Insulin and proinsulin were extracted from the tumor by the method of Davoren [20] and measured by radioimmunoassay. Proinsulin in samples of tumor extract or culture medium was measured by RIA with porcine insulin antibody and radioactive insulin after separation on G-50 Sephadex. Cyclic AMP was measured by RIA [21] with materials obtained from Collaborative Research, Inc. (Waltham, Mass.). Cyclic AMP-phosphodiesterase was measured by assay of $0.1 \mathrm{ml}$ aliquots of culture medium as previously described [22, 23]. Statistical comparisons were made by means of paired $t$-tests.

A portion of the tumor was fixed in formalin (10\%) and embedded in paraffin. Representative sections cut at 10 microns were stained with hematoxylin and eosin for routine histopathological evaluation. Some sections were stained with toluidine blue; others, following post-fixation with Bouin's solution, were stained with a modified aldehyde fuchsin - ponceau de xylidine [24].

\section{Results}

\section{Pre- and Post-Operative Patient Studies}

Preoperative oral glucose tolerance tests revealed fasting plasma insulin of $50 \mu \mathrm{U} / \mathrm{ml}$, with no significant increase following $100 \mathrm{~g}$ glucose load, although there was a significant serum glucose increase (prestimulus 
$72 \mathrm{mg} / 100 \mathrm{ml}$ to $125 \mathrm{mg} / 100 \mathrm{ml}$ poststimulus peak). Postoperatively, fasting plasma insulin values were in the normal range $(15-20 \mu \mathrm{U} / \mathrm{ml})$ and increased to a high of $85 \mu \mathrm{U} / \mathrm{ml}$ after oral glucose.

Intravenous glucose tolerance tests $(25 \mathrm{~g}$ load $)$ preoperatively resulted in very high glucose levels $(250 \mathrm{mg} / 100 \mathrm{ml}$ at $2 \mathrm{~min}$, declining linearly to 100 $\mathrm{mg} / 100 \mathrm{ml}$ by $45 \mathrm{~min}$ ) with a slightly elevated glucose disappearance rate, $k=1.93$ (normal $k=1.73$ ). However, only a small transitory increase in plasma insulin $(50 \mu \mathrm{U} / \mathrm{ml} 2$ minutes after stimulus, returning to prestimulus level of $30 \mu \mathrm{U} / \mathrm{ml}$ after $5 \mathrm{~min}$ ) was observed.

Intravenous Tolbutamide $(1.0 \mathrm{~g})$ preoperatively resulted in only a small rise in insulin (peak value 40 $\mu \mathrm{U} / \mathrm{ml}$ ) and a gradual decline in serum glucose (to 50 $\mathrm{mg} / 100 \mathrm{ml}$ ) over the $180 \mathrm{~min}$ test period. Postoperatively, a brisk increase in plasma insulin (to 100 $\mu \mathrm{U} / \mathrm{ml}$ ) and corresponding decline in serum glucose (from prestimulus $105 \mathrm{mg} / 100 \mathrm{ml}$ to $60 \mathrm{mg} / 100 \mathrm{ml}$ poststimulus) were observed following intravenous Tolbutamide.

Intravenous glucagon $(1.0 \mathrm{mg})$ preoperatively caused a significant rise in serum glucose (from prestimulus $50 \mathrm{mg} / 100 \mathrm{ml}$ to $100 \mathrm{mg} / 100 \mathrm{ml}$ peak), but no insulin response either to the glucagon itself, or, apparently, to the increased glucose level.

Plasma insulin levels were not increased by oral leucine prior to surgery. However, one month postoperatively, an unexpected slight increase in IRI (18 $\mu \mathrm{U} / \mathrm{ml}$ prestimulus to $30 \mu \mathrm{U} / \mathrm{ml}$ peak at $60 \mathrm{~min}$ ) was observed after oral leucine. Preoperatively plasma insulin levels were also unaffected by a combination of amino acids administered in the form of a beef meal. The patient experienced a generalized seizure after a $30 \mathrm{hr}$ preoperative fast. At seizure, his insulin:glucose ratio was abnormal: IRI $25 \mu \mathrm{U} / \mathrm{ml}$, glucose $40 \mathrm{mg} / 100$ $\mathrm{ml}$ (appropriately matched normal fasting controls in our laboratory have IRI $15-20 \mu \mathrm{U} / \mathrm{ml}$ and glucose 80-100 $\mathrm{mg} / 100 \mathrm{ml}$ ). Indeed, this patient's insulin : glucose ratios were persistently abnormal throughout preoperative tests.

\section{Tumor Pathology}

Histological sections stained with hematoxylin and eosin showed that the tumor mass had a thick connective tissue capsule, and was poorly vascularized. The consulting pathologist, without access to other data reported here, classified the hematoxylin/eosin stained sections as an "atypical benign islet cell adenoma." The tumor consisted predominantly of cuboidal, epithelial-like cells with pale, mildly basophilic cytoplasm, and a high nuclear : cytoplasmic ratio (Fig. 1).

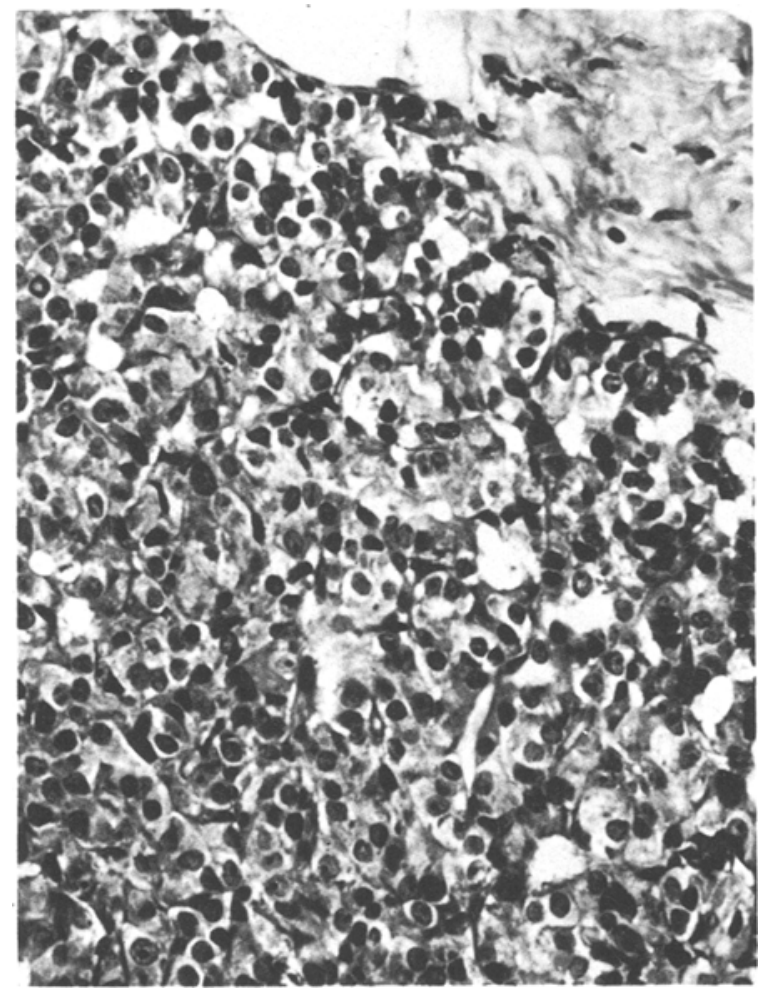

Fig. 1. Tumor pathology. Section showing typical histological architecture of tumor. Hematoxylin and eosin stain; final magnification $325 x$

There was slight variation in nuclear size and density, and few mitoses were detectable. Sections stained with aldehyde fuchsin demonstrated very few aldehyde fuchsin positive granules in the tumor cells, though islets in adjacent normal pancreatic tissue were well granulated. Toluidine blue stained sections revealed that the tumor cells were not metachromatic.

A portion of the tumor was extracted with acid alcohol, and insulin and proinsulin determined in the extract. Of the stored immunoreactive material, $23 \pm$ $1 \%$ eluted from the column with a proinsulin marker. A total of 0.9 units IRI was obtained from $44 \mathrm{mg}$ (wet weight) of the tumor.

\section{Tumor Cells in Culture}

Within the first week of culture, a large number of cells had migrated from the explants, and spread over the culture vessels. Observation of the living cells by inverted phase microscopy revealed morphological differences between cells in medium 199 and medium F12K. Cells in medium 199 were predominantly fibroblastic (Fig. 2A), while those in F12K were chiefly epithelial (Fig. 2B). These early morphological variations could not be correlated with either glucose or serum concentrations in the culture media. 

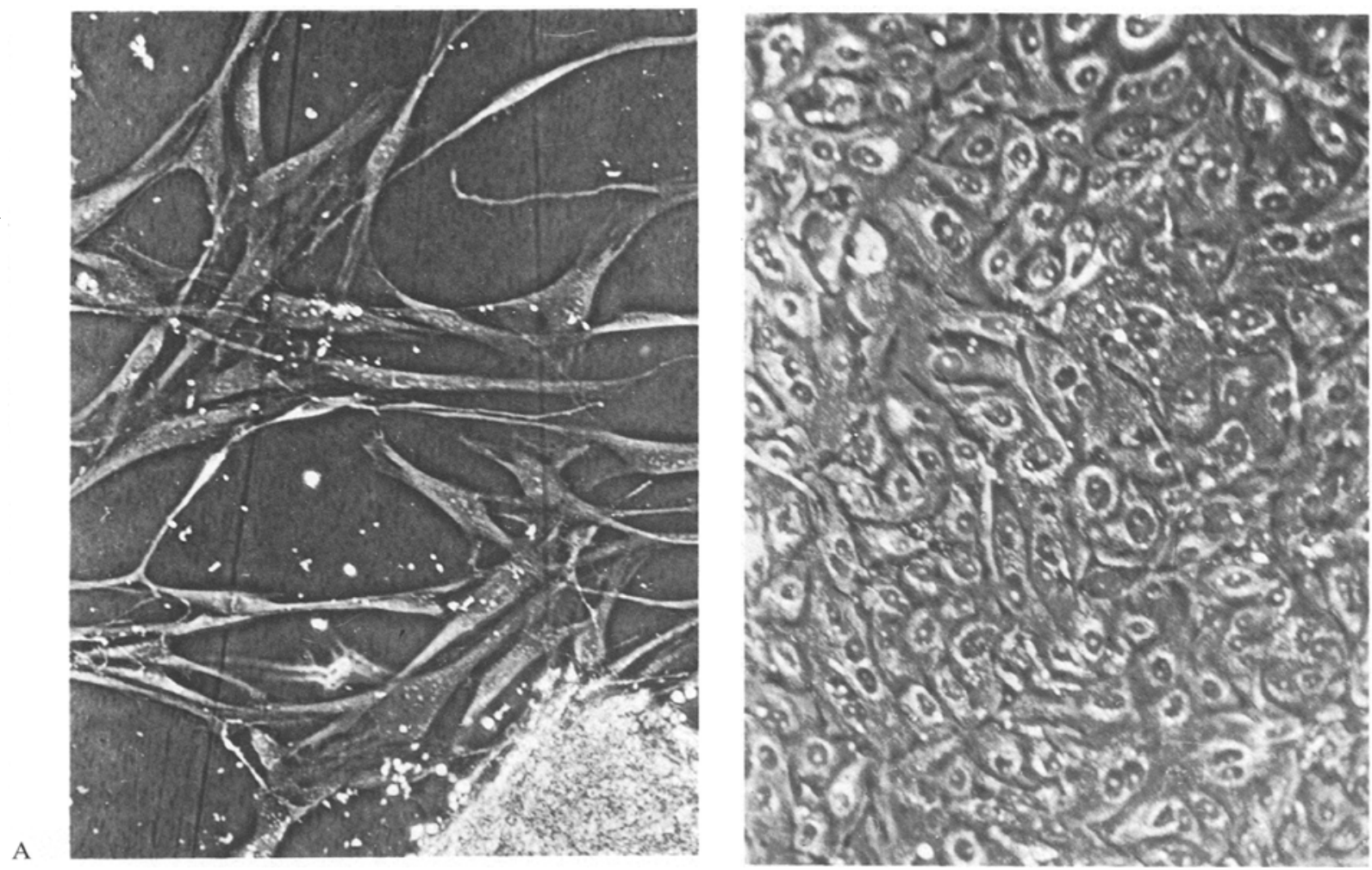

Fig. 2. Islet tumor cells in culture. (A) Typical fibroblast-like cells from cultures with medium 199. The tissue from which these cells migrated is shown in the lower right. Phase contrast photograph of unstained, living cells, 11 days after establishing primary culture. Final magnification, $350 \times$. (B) A sheet of epithelial-like cells from an explant cultured in medium. F12K for 11 days. Phase contrast photograph of living, unstained cells; final magnification $350 \times$

There were also marked differences between the two media with regard to the amount and persistence of immunoreactive insulin released over the observed periods. The amounts of insulin released during the first and second culture medium changes were compared for selected F12K and 199 cultures (Table 1). During these intervals, cultures on medium 199 decreased their insulin release significantly more $(P \leqslant$ 0.001 ) than those on medium F12K.

Table 1. Effectiveness of different culture media

\begin{tabular}{|c|c|c|c|}
\hline \multirow{2}{*}{$\begin{array}{l}\text { Primary Culture } \\
\text { Interval } \\
\text { (Days) }\end{array}$} & \multicolumn{2}{|c|}{$\begin{array}{l}\text { Insulin Released into Media } \\
(\mu \mathrm{U} / \text { culture } \pm \mathrm{S} \text {. E.) }\end{array}$} & \multirow{2}{*}{$\begin{array}{l}\mathrm{P}^{c} \\
(\leqslant)\end{array}$} \\
\hline & Medium 199(n) & Medium F12K(n) & \\
\hline $\begin{array}{l}1-4 \\
5-8\end{array}$ & $\begin{array}{r}287 \pm 45 \\
57 \pm 18\end{array}$ & $\begin{array}{l}297 \pm 65 \\
135 \pm 34\end{array}$ & $\begin{array}{l}\text { n. s. } \\
0.001\end{array}$ \\
\hline
\end{tabular}

a Most cultures using F12K released much more insulin than did comparable cultures with medium 199: for these calculations, low insulin producing $\mathrm{F} 12 \mathrm{~K}$ cultures were selected, so that release rates during the 1-4 day reference period were similar for both media.

$b$ Number of observations

c Paired $t$-test.
Since cultures were prepared by placing explants in culture vessels, it was impossible to obtain identical amounts of tissue in each vessel. Therefore, for broad comparison of rates of insulin release all IRI values were expressed as a percentage of the amount released during the 4 th through 8 th days of primary culture (i. e., during the second medium change). This data transformation permits direct comparison of IRI between cultures having different numbers of cells, since the IRI released during the second medium change becomes $100 \%$ for each culture vessel.

Initially, cultures on medium 199 released an average of $287 \mu \mathrm{U}$ IRI/culture/4 days. Though insulin was detectable through 50 days of culture, the release rates declined rapidly (Fig. 3). By contrast, cultures on medium F12K initially released an average of $508 \pm$ $63 \mu \mathrm{U}$ IRI/culture/4 days on low glucose and $849 \pm$ $36 \mu \mathrm{U}$ IRI/culture/4 days on high glucose, and continued to release insulin into the medium for much longer periods of primary culture (Fig. 4). In cultures with medium 199, medium glucose levels did not affect insulin release rates. However, for medium F12K, cultures with $326 \mathrm{mg}$ glucose $/ 100 \mathrm{ml}$ medium continued to release insulin in higher amounts than those grown with glucose at $126 \mathrm{mg} / 100 \mathrm{ml}$ medium (Fig. 4) 


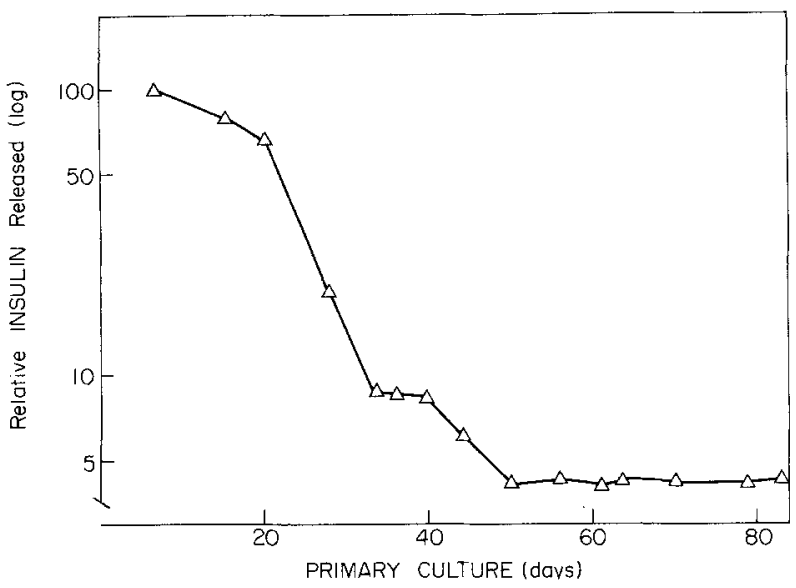

Fig. 3. Insulin released by cells cultured in medium 199. Relative amount of insulin detected in culture medium at each plotted point is calculated as a percentage of the amount released during the second medium change. As noted in text, the second medium change baseline IRI for these cultures was $287 \mu \mathrm{U}$ IRI/culture. Each point shows the mean of observations from 5 or more culture vessels, and represents the amount of insulin released in the previous 4 days

for 2 months in culture. Subsequently in medium F12K the insulin release rates appeared to stabilize regardless of the medium glucose concentration. These data demonstrate the superiority of medium F12K for present purposes: the remaining experiments to be reported employed cultures on medium F12K, with either 126 or $326 \mathrm{mg}$ glucose $/ 100 \mathrm{ml}$ medium.

Primary cultures maintained for 40 days in F12K with $126 \mathrm{mg}$ glucose $/ 100 \mathrm{ml}$ were transferred to $\mathrm{F} 12 \mathrm{~K}$ with $326 \mathrm{mg}$ glucose $/ 100 \mathrm{ml}$ for short $(6.5 \mathrm{hrs})$ or long (5.5 days) periods. During the short term change of glucose level, a marginally significant $(P \leqslant 0,05)$ decrease in insulin release was observed; during the long

Table 2. Absence of glucose response of cultured cells

\begin{tabular}{|c|c|c|c|c|c|}
\hline \multirow{2}{*}{\multicolumn{2}{|c|}{$\begin{array}{l}\text { Glucose concentration } \\
\text { in medium } F 12 \mathrm{~K}\end{array}$}} & \multicolumn{4}{|c|}{$\begin{array}{l}\text { Insulin Release Ratio } \\
\mu \mathrm{U} / \text { culture Stimulus } \\
\end{array}$} \\
\hline & & \multicolumn{4}{|c|}{$\mu \mathrm{U} /$ culture Control } \\
\hline $\begin{array}{l}\text { Control } \\
(\mathrm{mg} / 100 \mathrm{ml})\end{array}$ & $\begin{array}{l}\text { Stimulus } \\
(\mathrm{mg} / 100 \mathrm{ml})\end{array}$ & $6.5 \mathrm{hrs}$ & $(n)^{b}$ & 5.5. days & $(n)^{b}$ \\
\hline 126 & 326 & 0.84 & $(5)$ & 0.97 & $(8)$ \\
\hline 326 & 126 & 0.78 & $(5)$ & 1.20 & (5) \\
\hline
\end{tabular}

a Insulin released by each culture during the designated stimulus period was divided by the insulin released by the same culture during an identical (pre-stimulus) control period. Absolute insulin release rates varied widely among cultures used $(6 \mu \mathrm{U}$ to $750 \mu \mathrm{U})$.

b Number of observations. Paired $t$-tests indicated marginal significance $(P \leqslant 0.05)$ for the short term stimuli, but no significant difference during the longer stimuli.

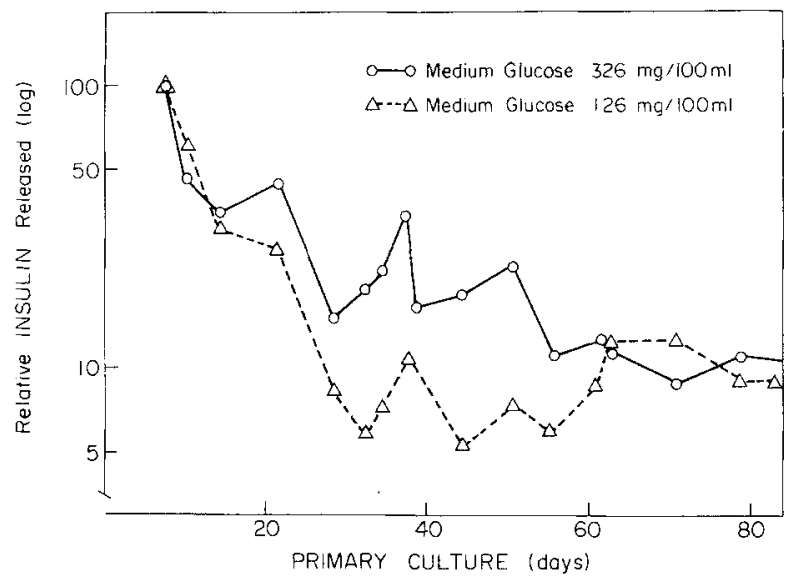

Fig. 4. Insulin released by cells cultured in medium F12K. Relative insulin release calculated as in Fig. 3, and described in text. Absolute insulin release during the second medium change averaged 508 $\pm 63 \mu \mathrm{U} /$ culture with $126 \mathrm{mg}$ glucose $/ 100 \mathrm{ml}$ medium and $849 \pm 36$ $\mu \mathrm{U} /$ culture with $326 \mathrm{mg}$ glucose $/ 100 \mathrm{ml}$ medium. Each plotted point shows the mean of observations from 5 or more culture vessels, and represents the amount of insulin released during the previous 4 days

term experiment, no significant difference in insulin release rate was observed (Table 2). The reverse experiment (primary cultures maintained on $326 \mathrm{mg}$ glucose $/ 100 \mathrm{ml} \mathrm{F} 12 \mathrm{~K}$ changed to $\mathrm{F} 12 \mathrm{~K}$ with $126 \mathrm{mg}$ glucose $/ 100 \mathrm{ml})$ also exhibited a slight $(P \leqslant 0.05)$ decrease in insulin production after short $(6.5 \mathrm{hrs})$ but not after long term (5.5 days) exposure (Table 2 ).

The usual leucine concentration in $\mathrm{F} 12 \mathrm{~K}$ is $0.2 \mathrm{mM}$, ignoring the minute quantities introduced by serum supplements. When leucine levels were increased to $10 \mathrm{mM}$ for $24 \mathrm{hrs}$, those cultures having $126 \mathrm{mg}$ glucose $/ 100 \mathrm{ml}$ released insulin at $84 \%$ of control value, whereas cultures in $326 \mathrm{mg}$ glucose $/ 100 \mathrm{ml}$ medium released insulin at $131 \%$ of control values. Paired $t$-tests revealed that neither change was statistically significant.

To examine the role of cyclic AMP in insulin release by the cultured cells, cultures were exposed to theophylline $(2 \mathrm{mM})$ in culture media for $24 \mathrm{hr}$ intervals. Theophylline treated cultures with medium glucose of $126 \mathrm{mg} / 100 \mathrm{ml}$ released insulin at $122 \%$ of control; those with $326 \mathrm{mg}$ glucose $/ 100 \mathrm{ml}$ released insulin at $95 \%$ of control. Neither change was statistically significant. Theophylline, a phosphodiesterase inhibitor, increased the level of cyclic AMP in the culture media to which it was added by an order of magnitude to 20 to 40 picomoles $/ \mathrm{ml}$ medium; this increase was not associated with any detectable difference in cyclic AMP-phosphodiesterase activity in culture media.

Samples of culture medium containing high levels of insulin (greater than $200 \mu \mathrm{U} / \mathrm{ml}$ ) from several cultures were pooled, and proinsulin and insulin levels meas- 
ured by RIA following separation on G-50 Sephadex. Approximately $90 \%$ of the IRI added was recovered from the column, and $5 \%$ of this amount eluted in the region of a porcine proinsulin marker. Thus, the cultured cells apparently were not releasing abnormally high proportions of the precursor protein during culture.

Glucagon radioimmunoassay of $0.1 \mathrm{ml}$ aliquots of the same medium pool used for insulin/proinsulin determination (i. e., high insulin level) failed to detect glucagon, though the method is sensitive to $4 \mathrm{pg} / \mathrm{ml}$. This observation strongly suggests that our cultures were free of metabolically competent pancreatic A-cells.

Explants which initiated primary cultures were removed when cells had spread onto the culture surface. When these cells had further spread (presumably by both mitosis and migration) over the majority of the culture plates, subcultures were prepared by enzymatic (CTCm) dispersal. Serially subcultured cells have remained viable, and continued to release insulin for extended periods (Fig. 5). Phase contrast microscopic examination of the living subcultures showed that the majority ( 70 to $90 \%$ ) of the cells were morphologically fibroblastic, even though cultures continued to release insulin. The few cultures which have been sacrificed for staining have failed to reveal any aldehyde fuchsin positive granulation. These obervations suggest that retention of epithelial cell morphology is not a prerequisite for retention of organ specific function in this culture system. The original tumor had few aldehyde fuchsin granules (in the face of substantial extractable insulin levels) and this characteristic has apparently been preserved in culture.

\section{Discussion}

Evaluation of insulin synthesis and secretion mechanisms in vivo must necessarily include an analysis of both direct and indirect effects on the pancreatic B-cell. The concept of employing a cell culture system to eliminate indirect effects, as well as other variables inherent in whole organism studies, has thus far not proven entirely satisfactory. Primary cultures of "normal" pancreatic B-cells gradually lose their ability to synthesize and secrete insulin. Further, successful clonal subculture, which could potentially eliminate the other cell types found in primary cultures, has not yet been reported for the pancreatic B-cell.

In evaluating a particular insulinoma in cell culture, it is essential that the diverse characteristics of such tumors be considered. Data reported here are consistent with a tumor capable of synthesizing and se-

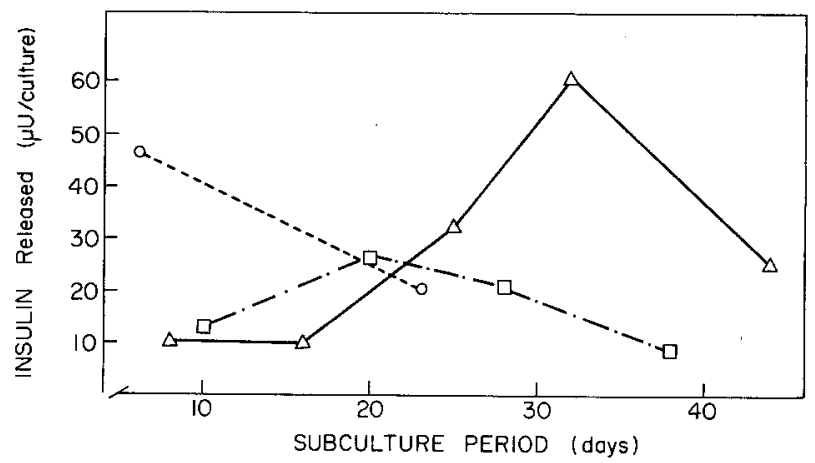

Fig. 5. Insulin released by subcultured cells in medium F12K. Culture medium contained $326 \mathrm{mg}$ glucose $/ 100 \mathrm{ml}$. Triangles: subculture prepared from 40 day old primary culture. Circles: subculture prepared from 45 day old primary culture. Squares: second passage subculture prepared from monolayered plate 21 days after that plate had been initiated from 40 day old primary culture

creting insulin, but not under normal metabolic control, either in the patient or in the cell culture. Our patient's response to secretogogues was similar to that recently reported for another atypical insulinoma [25]. The extractable insulin of the tumor $(20 \mathrm{U}$ per gram wet weight) and the proportion of proinsulin $(23 \%)$ are considerably higher than those of normal human pancreas [26, 27]. An insulinoma consisting of a homogeneous population of islet-like cells might be compared more appropriately to isolated islets than to whole pancreas, which contains only about one percent islet tissue. This tumor contained only 10 to $15 \%$ of the insulin content expected in a similar mass of isolated islet tissue. This is consistent with the high secretory rate indicated by this patient's abnormally high fasting plasma insulin level, and with reported insulin levels in 29 of 30 insulinomas studied by Creutzfeldt et al. [28]. That secretory stimuli failed to increase insulin release either in the patient or in culture, in spite of an abnormally high insulin store, indicates a defective release mechanism; that neither the tumor nor cultured cells contained aldehyde fuchsin granules strengthens this hypothesis, and suggests that the defect might involve granule formation.

Failure of insulin release of cultured cells in response to increased glucose over periods of $6.5 \mathrm{hrs}$ and 5.5 days confirms the impairment of insulin release suggested by the patient's failure to respond to oral or intravenous glucose, glucagon, tolbutamide or leucine. In the patient, the lack of response to glucose indicates an inhibition of both tumor cells and normal pancreatic B-cells, possibly because sufficient insulin was being released by tumor cells to directly or indirectly maintain low serum glucose levels, and thus suppress B-cell function [29].

Leucine loading characteristically leads to an increased insulin release in many insulinoma patients 
$[30,31]$. Some, like our patient, fail to respond, possibly because the amino acid stimulus is effective only in the presence of adequate glucose levels [32]. Our cultured adenoma cells, however, failed to release insulin above baseline in response to leucine even in the presence of up to $326 \mathrm{mg}$ glucose per $100 \mathrm{ml}$ medium. It is thus reasonable to conclude that this patient's failure to respond to leucine or to a beef meal was the result not of his chronic and uncontrolled hypoglycemia but of a metabolic defect in the insulin synthesizing cells he possessed. Because normal fasting glucose levels could not be maintained in the patient during leucine loading, this conclusion could not be drawn without the observations under controlled glucose levels possible only in a cell culture system.

Cultured cells failed to release insulin in response to theophylline, even though this treatment did cause increases in cyclic AMP in the culture medium, confirming that the theophylline reached cell membranes, and suggesting that the defect was at a level other than that controlled by cyclic AMP. However, it cannot be ruled out that the observed increases in medium cyclic AMP were due to effects of theophylline on cultured cell types other than insulin producing tumor cells.

Minimal response to tolbutamide occurs in about $20 \%$ of insulinomas [31]. We observed minimal tolbutamide response ( $40 \mu \mathrm{U} / \mathrm{ml}$ peak), relatively high insulin levels in vivo, and high release rates in culture. These data, combined with the insulin content of the tumor, are consistent with the hypothesis that the primary defect was in a "disturbed [insulin] storage and release mechanism, and not pathological biosynthesis of the hormone" [27].

In retrospect, it appears that all our observations are consistent with the hypothesis that the major characteristics of this particular islet cell adenoma were maintained during a period of over seven months in cell culture. Perhaps the rarity of islet cell adenomas (some 1,000 cases reported between 1902 and 1973 [33]) is responsible for the paucity of reports of successful culture. We believe, however, that the inadequacy of the culture conditions usually employed is also a major factor.

The long term success of our cultures on medium F12K is in marked contrast not only to our cultures of the same tumor with medium 199, but also to previous reports using several culture media. It is noteworthy that the parent medium of F12K, Ham's F12 [34], was devised specifically for growth of cells from clonal densities (most cell culture media were developed for growth of large numbers of rapidly dividing, generally undifferentiated cells), and that F12K itself has been employed successfully for culture of functional, diploid cell types from several species, including man
$[35,36]$. The advantage of medium $\mathrm{F} 12 \mathrm{~K}$ in this paper is clearly indicated by the longevity of the cultures, and by the comparison of insulin release during early culture periods with medium F12K and medium 199 (Table 1).

Of even greater importance is our success in preserving functional characteristics of subcultured cells for long periods. Preparation of subcultures by means of enzymatic dispersal is likely to result in irreversible membrane damage [37]. Minimal damage appears to have occured in this case with the use of CTCm, since the cells remained viable for long periods, and retained their ability to secrete insulin into culture medium. Without doubt, the presence of chicken serum (known to be free of trypsin inhibitors) and of methyl cellulose in the dispersal medium was at least in part responsible for minimal cell damage, since these components should protect cell membranes during cell dispersal.

\section{Addendum}

After this paper was submitted, Maclaren, Huang and Fogh (Lancet i, 997-999, 1975) referred to a cell line established in 1959 from an insulinoma. After at least 40 passages, their cells "produced insulin at concentrations of $10-20 \mu \mathrm{U}$ per ml of culture medium after 3 days." Neither the cell line characteristics nor culture methods are detailed.

Acknowledgements. This work was supported by Clinical Investigatorship 1942 and Clinical Research Center Grant RR-00211 (W.C. D.), by Veterans Administration Hospital Grant 8036 and U. S.P. H. S. Grant AM-15509 (S. S. S.), by U. S. P. H. S. Grant AM-18022 (S. S. S. and W. C. D.), and by U. S. P. H. S. Grants AM-14248 and RR-05423 (L. R. M.). Many of the radioimmunoassay and statistical calculations were completed through the UTCHS Cardiovascular Computer Project, supported by U. S. P. H. S. Grant HL-09495.

\section{References}

1. Murray, M. R., Bradley, C. F.: Two island-cell adenomas of the human pancreas cultivated in vitro. Amer J. Cancer 25, 98-107 (1935)

2. Sando, H., Kemmler, W., Rubenstein, A. H., Steiner, D. F.: Studies on insulin biosynthesis and secretion in isolated islets and a cultured beta cell tumor. In: Insulin action (ed. I. B. Fritz), pp. 77-113. New York: Academic Press 1972

3. Yip, C. C., Schimmer, B. P.: Human pancreatic islet tumor cell maintained in vitro. Diabetologia 9, 251-254 (1973)

4. Chick, W. L., Lauris, V., Soeldner, J. S., Tan, M. H., Grinbergs, M.: Monolayer culture of a human pancreatic beta-cell adenoma. Metabolism 22, 1217-1224 (1973)

5. Marliss, E. B., Wollheim, C. B., Blondel, B., Orci, L., Lambert, A. E., Stauffacher, W., Like, A. A., Renold, A. E.: Insulin and glucagon release from monolayer cell cultures of pancreas from newborn rats. Europ. J. clin. Invest. 3, 16-26 (1973) 
6. Macchi, I., Beyer, W. R., Gapp, D. A., Blaustein, E. H., Beaser, S. B.: Monolayer cultures derived from neonatal hamster pancreas: stimulation of immunoractive insulin secretion and biosynthesis. Proc. Soc. exp. Biol. (N. Y.) 143, 335-339 (1973)

7. Hilwig, I.: Observations on mammalian pancreatic cells grown in monolayer cultures: V. Quantitative study of nucleolar extrusion in rat pancreatic cells cultivated in vitro. Acta biol. Acad. Sci.hung. 24, 207-214 (1973)

8. Chick, W. L.: Beta cell replication in rat pancreatic monolayer cultures: effects of glucose, tolbutamide, glucocorticoid, growth hormone and glucagon. Diabetes 22, 687-693 (1973)

9. Leiter, E. H., Coleman, D. L., Waymouth, C.: Cell culture of the endocrine pancreas of the mouse in chemically defined media. In Vitro 9, 421-433 (1974)

10. Hanks, J. H., Wallace, R. E.: Relation of oxygen and temperature in the preservation of tissues by refrigeration. Proc. Soc. exp. Biol. (N. Y.) 71, 196-201 (1949)

11. Kaighn, M. E.: "Birth of a culture" - source of postpartum anomalies. J. nat. Cancer Inst. 53, 1437-1442 (1974)

12. Moscona, A.: Cell suspensions from organ rudiments of chick embryos. Exp. Cell Res. 3, 535-539 (1952)

13. Kaighn, M. E.: Human liver cells. In: Tissue culture: methods and applications (eds. P. F. Kruse, Jr., M. K. Patterson, Jr.), pp. 54-58. New York: Academic Press 1973

14. Morgan, J. F., Morton, H. J., Parker, R. C.: Nutrition of animal cells in tissue culture. I. Initial studies on a synthetic medium. Proc. Soc. exp. Biol. (N. Y.) 73, 1-8 (1950)

15. Brown, M. E.: Ultra-micro sugar determinations using 2, 9-dimethyl-1, 10-phenanthroline hydrochloride (neocuprine). Diabetes 10, 60-62 (1962)

16. Morgan, C. R., Lazarow, A.: Immunoassay of insulin: two antibody system: plasma insulin levels of normal, subdiabetic and diabetic rats. Diabetes 12, 115-126 (1963)

17. Desbuquois, B., Aurbach, G. D.: Use of polyethylene glycol to separate free and antibody bound peptide hormones in radioimmunoassay. J. clin. Endocr. 33, 732-738 (1971)

18. Yalow, R. S., Berson, S. A.: Immunoassay of endogenous plasma insulin in man. J. clin. Invest 39, 1157-1175 (1960)

19. Unger, R. H., Ketterer, H., Dupré, J., Eisentraut, A. M.: The effects of secretin, pancreozymin and gastrin upon insulin and glucagon secretion in anesthetized dogs. J. clin. Invest. 46, 630-645 (1967)

20. Davoren, P. R.: The isolation of insulin from a single cat pancreas. Biochim. biophys. Acta (Amst.) 63, 150-153 (1962)

21. Steiner, A. L., Kipnis, D. M., Utiger, R., Parker, C. W.: Radioimmunoassay for the measurement of adenosine $3^{\prime}: 5^{\prime}$-cyclic phosphate. Proc. nat. Acad. Sci. (Wash.) 64, 367-373 (1969)

22. Thompson, W. J., Appleman, M. M.: Multiple cyclic nucleotide phosphodiesterase activities from rat brain. Biochemistry 10, 311-316 (1971)

23. Solomon, S. S.: Phosphodiesterase activity of rat and human adipose tissue. J. Lab clin. Med. 79, 598-610 (1972)

24. Lazarow, A., Wells, L. J., Carpenter, A. M., Hegre, O. D., Leonard, R. J., McEvoy, R. C.: Islet differentiation, organ culture and transplantation. Diabetes 22, 877-912 (1973)
25. Lucke, C., Grögler, F., Mitzkat, H. J.: Der interessante Fall: Insulinom. Med. Klin. 69, 1456-1459 (1974)

26. Steinke, J., Soeldner, J. S., Renold, A. E.: Measurement of small quantities of insulin-like activity with rat adipose tissue. IV. Serum insulin-like activity and tumor insulin content in patients with functioning islet cell tumors. J. clin. Invest. $\mathbf{4 2}$, 1322-1329 (1963)

27. Creutzfeldt, C., Track, N. S., Creutzfeldt, W.: In vitrostudies of the rate of proinsulin turnover in seven human insulinomas. Europ. J. clin. Invest. 3, 371-384 (1973)

28. Creutzfeldt, W., Arnold, R., Creutzfeldt, C., Deuticke, U., Frerichs, H., Track, N. S.: Biochemical and morphological investigation of 30 human insulinomas. Diabetologia 9, 217-231 (1973)

29. Goodner, C. J., Porte, D., Jr.: Determinants of basal islet secretion in man. In: Handbook of Physiology, Section 7, Volume 1. (eds. D. F. Steiner, N. Freinkel), pp. 597-609. Washington D. C.: American Physiological Society 1972

30. Fajans, S. S., Floyd, J. C., Jr.: Stimulation of islet cell secretion by nutrients and by gastrointestinal hormones released during digestion. In: Handbook of Physiology, Section 7, Volume 1. (eds. D. F. Steiner, N. Freinkel), pp. 473-493. Washington D. C.: American Physiological Society 1972

31. Floyd, J. C., Jr., Fajans, S. S., Knopf, R. F., Conn, J. W.: Plasma insulin in organic hyperinsulinism: comparative effects of tolbutamide, leucine and glucose. J. clin. Endocr. 24, 747-760 (1964)

32. Malaisse, W. J., Malaisse-Lagae, F.: Stimulation of insulin secretion by noncarbohydrate metabolites. J. Lab. clin. Med. 72, 438-448 (1968)

33. Shatney, C. H., Grage, T. B.: Diagnostic and surgical aspects of insulinoma: a review of twenty-seven cases. Amer. J. Surg. 127, 174-184 (1974)

34. Ham, R. G.: Clonal growth of mammalian cells in a chemically defined synthetic medium. Proc nat. Acad. Sci. (Wash.) 53, 288-293 (1965)

35. Douglas, W. H. J., Kaighn, M. E.: Clonal isolation of differentiated rat lung cells. In Vitro 10, 230-237 (1974)

36. Kaighn, M. E., Prince, A. M.: Production of albumin and other serum proteins by clonal cultures of normal human liver. Proc. nat. Acad. Sci. (Wash.) 68, 2396-2400 (1971)

37. Cahn, R. D., Coon, H. G., Cahn, M. D.: Cell culture and cloning techniques. In: Methods in development biology (eds. F. H. Wilt, N. K. Wessells), pp. 493-530. New York: Thomas Y. Crowell Company 1967

Prof. L. R. Murrell

Dept. of Anatomy

Univ. of Tennessee

Center for the Health Sciences

875 Monroe Avenue

Memphis, Tennessee 38163

USA 